\title{
Molar Fraction of Carbon, Nitrogen and Mineral Sources Regulate Antibiotic Biosynthesis Pattern in Pseudomonas Fluorescens CHA0
}

\author{
Sumant Chaubey ${ }^{1}$, Shweta Talreja ${ }^{1}$, Naresh Kumar $\mathrm{G}^{2}$ and Archana $\mathrm{G}^{1 *}$ \\ ${ }^{1}$ Department of Microbiology \& Biotechnology Centre, The Maharaja Sayajirao University of Baroda, India \\ ${ }^{2}$ Department of Biochemistry, The Maharaja Sayajirao University of Baroda, India
}

Submission: January 4, 2017; Published: January 20, 2017

*Corresponding author: Archana G, Department of Microbiology and Biotechnology centre, Faculty of Science, The M.S. University of Baroda, Vadodara, Gujarat, India; Tel: 0091-265-2794396; Fax: 0091-265-2792508; E-mail: archanagayatri@yahoo.com/garchana@india.com

\begin{abstract}
Fluorescent Pseudomonas species inhibit fungal phytopathogens under laboratory and greenhouse conditions, but in field trials the inconsistent performance is observed, which is thought to be due to variations in abiotic and biotic factors in/around the rhizosphere. Combination of nutrients and mineral components relevant to root zone and its effect on the antibiotic biosynthesis by fluorescent Pseudomonas species important for the understanding of biocontrol activity in the rhizosphere. Using Stat ease 8, and fractional factorial design sixteen combinations of four macronutrient (glucose, citrate, nitrate, phosphate) and three essential elements ( $\mathrm{Fe}, \mathrm{Zn}$ and $\mathrm{Mo}$ ) obtained, and studied for the main effects and higher order interactions, on the culture growth, antifungal activity toward Rhizoctonia bataticola, and on the biosynthesis of pyrrolnitrin (PRN), 2, 4-diacetyphloroglucinol (DAPG) and pyoluteorin (PLT) in the model biocontrol strain Pseudomonas fluorescens CHA0 (Pf CHA0).
\end{abstract}

Citrate, glucose, $\mathrm{Fe} 2+, \mathrm{Zn} 2+$ individually and citrate with glucose, found to be supportive while triple combination of citrate, glucose and nitrate is highly inhibitory to Pf CHA0 growth, antifungal activity as well as antibiotic biosynthesis. Principal Component Analysis revealed that 2 day antifungal is positively correlation with PLT maximally followed by OD, PRN and DAPG. Fifth day antifungal activity showed positive correlation maximally with PRN followed by OD, and PLT. Bio-control supporting nutrient combinations showed effective protection of Vigna radiata from $R$. bataticola. Present study will be helpful for improving the reliability and application potential to the various soil types and different plant rhizosphere types.

Keywords: Nutrients; Antibiotics biosynthesis; PfCHA0

\section{Introduction}

Many species of root-associated beneficial bacteria have the ability to reduce the severity of diseases caused by soil borne fungal phytopathogens and to increase plant yields under laboratory and greenhouse conditions and are considered important biocontrol inoculants for sustainable agricultural practices [1-3], Whipps et al. (2001). However, in field trials the inconsistent performance of bacterial biocontrol agents has been observed from site to site and from year to year $[4,5]$ which is a major concern for their large-scale application [6]. A thorough understanding the sources of variability in field performance, which could be due to variations in environmental conditions, abiotic and biotic, that the bacterial inoculants confront in the rhizosphere is an important aspect of study. Many factors are found to affect the performance of biocontrol agents, for example, there is a clear link between soil pH and mineral concentrations and the variability in biocontrol activity of both fungal and bacterial inoculants against root diseases [7-9].

Biosynthesis of antimicrobial compounds by bio-control bacteria is modulated by the total concentration and type of carbon (C) source, nitrogen (N) source, amino acids, metal ions such as $\mathrm{Fe}^{+}, \mathrm{Mo}^{+}$and $\mathrm{Zn} 2^{+}$and other compounds found abundantly in plant root exudates but lacking in bulk soil [10-13]. C-Sources contribute to the variability of bio-control in different soils and on host crops that differ in root exudates composition Latour et al. (1996). Comparison of root exudates composition of cucumber, tomato, sweet pepper and grass revealed that it contained more organic acids than sugars and citric, malic, and succinic acid were major organic acids and fructose, glucose and to a minor extent, xylose, were major sugars Kuiper et al. (2002). Plant specificity of bio-control bacteria has been demonstrated 
at both the species and cultivar level which is generally been attributed to differential utilization of the various carbon and nitrogen compounds found in exudates and its effects on growth [14].

Fluorescent pseudomonads are one of the most wellstudied group of biocontrol and plant growth promoting rhizobacteria (PGPR) that have the ability to produce diverse antifungal metabolites of different efficacy, mode of action and stability and thereby protect the crop from attack by different fungal pathogens Raaijmakers et al. (2002) [6,15]. Important antifungal metabolites which contribute to biocontrol by fluorescent Pseudomonas include 2,4-diacetylphloroglucinol (DAPG), pyoluteorin (PLT), pyrrolnitrin (PRN), phenazines (PHZ), lipopeptides and hydrogen cyanide Nielsen et al. (2002), Raaijmakers et al. (2002), Haas \& Keel (2003) [16,17]. Certain biocontrol strains of Pseudomonas produce multiple antibiotics with overlapping or different degrees of activity against specific pathogens. For instance, the biocontrol agents Pf CHA0 and Pf-5 produce the phenolic compounds DAPG, PLT and PRN Loper et al. (1997), Raaijmakers et al. (2002) [18].

Regulatory pathways responding to these nutritional and environmental factors are generally integrated into to respond to these signals on various additional regulatory elements, global environmental and physiological regulators such as GacS-GacA, RpoS, and CRP $[19,20]$ and there is evidence that rhizospheric microbes such as Pseudomonas sense the availability of diverse nutritional factors as exogenous signal, activate small RNAs (sRNAs) that bind RsmA/ CsrA proteins are typically produced under the positive control of a two-component system termed GacS/GacA for global activation of antibiotic biosynthesis [21], Babitzke \& Romeo et al. (2007).

Pf CHA0 respond to exogenous regulatory signal(s) by activating Gac/ Rsm a membrane-bound sensor kinase Laville et al. (1992) [22] the biosynthesis of bacterial auto inducers, rpoD and the cellular levels of mRNAs, stable RNAs (i,e. rRNAs and tRNAs), small RNAs (RsmX, RsmY and RsmZ) when cells reach high population densities [23]; Valverde et al. (2003); Kay et al. (2005). When bacterial cells are growing in batch culture, the GacS-GacA-dependent phenotypes are expressed mostly when the culture is in the transition from exponential to stationary phase Heeb \& Haas (2001). An additional level of control may be provided by the relative concentrations of the housekeeping $\sigma$ factor RpoD and the stress and stationary phase $\sigma$ factor RpoS in the bacterial cell. In PfCHA0, over expression of the housekeeping $\sigma$ factor RpoD enhances DAPG and PLT biosynthesis in vitro and in the rhizosphere, resulting in improved bio control depending on the plant species Maurhofer et al. (1992) [24,25].

Likewise, an rpoS mutant of the related strain Pf-5 shows strongly enhanced PLT and DAPG biosynthesis [26] whereas rpoS over expression in strain Pf CHA0 was found to shut off PLT biosynthesis Haas \& Keel, et al. (2003). Two-component regulatory cascade composed of the sensor kinase GacS and the response regulator GacA that positively controls antibiotic biosynthesis upon activation by a yet unidentified quorum sensing-signal Haas \& Keel, et al. (2003); Valverde et al. (2003) [22]. Numerous biotic and abiotic signals may also influence the production of these antifungal compounds, including different mineral and carbon sources as well as metabolites released by micro-organisms and plants [27-29]. Quantitative and/ or qualitative differences in the sugar, nitrogen, phosphate and mineral component of root exudates could determine the optimal environment for the effective bio-control mechanism in given crop-pathogen systems [24,30].

Maria Pechy-Tarr et al. [31] reported that $\mathrm{rpoN}$ is a key regulator of bio control activity in plant-beneficial pseudomonad and recently, Kumar and Shimizu, 2010 reported that as C/N ratio get increased, and transcript level of rpoN (which encodes $\sigma^{54}$ ) increases in E. coli. So the role of rpoN in bio control activity by fluorescent pseudomonads under varied $\mathrm{C} / \mathrm{N}$ ratio could not be ignored. The importance of organic acids as carbon sources for growth of Pseudomonas spp in the rhizosphere was shown previously by De Weert et al. [32] who demonstrated that mutants of the good colonizer P. fluorescens WCS365 with mutations in genes encoding malate/quinone oxidoreductase or cisaconitate hydratase, enzymes of the tricarboxylic acid cycle, are poor competitive colonizers of the tomato root compared with the parental strain. Our results add another point to plant specificity i.e. the influence of combination of root exudates components on the biosynthesis of antimicrobial metabolites by fluorescent Pseudomonas and increase its competence and survival efficiency in rhizosphere.

In the present study, we have studied the well-characterized biocontrol agent $P f$ CHAO $[2,18]$ to get insight into the pattern of biosynthesis of the antifungal compounds DAPG, PLT and PRN that are major determinants of the biocontrol activity in this strain under the different combinations of nutritional factors. Along with glucose, citrate is also studied as an alternate $\mathrm{C}$ source, since citrate is preferred C source Pseudomonas and it is the one of major constituent of root exudates. The results of this study provide

A. Insight into the possible biosynthetic regulation of antibiotics by complex of organic and inorganic component present in the rhizosphere,

B. Limited number of factors and their combinations for intensive study in situ,

C. The factors that can be manipulated to improve bacterial inoculants and

D. The application prospect of the biocontrol strains based on the rhizosphere and soil type for better bio-control potential.

\section{Methods}

\section{Bacterial maintenance and growth conditions}

Pf CHA0 (kindly provided by Dr. Fabio Rezzonico, Agroscope Changins-Wädenswil Zurich, Switzerland, was routinely 
maintained on King's B medium plates (Hi-media, India) at $28{ }^{\circ} \mathrm{C}$ and stored for long term in $0.8 \%$ nutrient broth with $0.5 \%$ yeast extract (NBY) broth with $40 \%$ glycerol at $-80^{\circ} \mathrm{C}$. Starter cultures were grown in $10 \mathrm{ml}$ dilute (1/5-strength) NBY broth in $20 \mathrm{ml}$ test tubes for $12 \mathrm{~h}$ at $28{ }^{\circ} \mathrm{C}$ at $150 \mathrm{rpm}$, yielding approximately $10^{9} \mathrm{CFU} / \mathrm{ml}$. For further growth, $20 \mathrm{ml}$ of dilute (1/5-strength) NBY broth in 100-ml Erlenmeyer flasks was inoculated with $100 \mu \mathrm{l}$ of starter bacterial. Autoclaved medium was amended with different combinations of following seven components: filter-sterilized solutions of KNO3 (10mM), KH2PO4 $(\mathrm{Pi}, 10 \mathrm{mM}), \quad \mathrm{FeSO}_{4} .7 \mathrm{H}_{2} \mathrm{O} \quad\left(\mathrm{Fe}^{2+}, 0.5 \mathrm{mM}\right), \quad \mathrm{Mo}_{7}(\mathrm{NH} 4)_{6} \mathrm{O}_{24} \cdot 4 \mathrm{H}_{2} \mathrm{O}$ $\left(\mathrm{Mo}^{2+}, 0.5 \mathrm{mM}\right), \mathrm{ZnSO} 4.7 \mathrm{H} 2 \mathrm{O}(\mathrm{Zn} 2+, 0.35 \mathrm{~m})$ and with autoclaved stock solutions of glucose and citrate to give final concentration of $100 \mathrm{mM}$. Rhizoctonia bataticola causal organism of dry root rot of Vigna radiata, was maintained on potato dextrose agar slants (PDA, Hi-media, India).

\section{Design of experiment for the combinations of nutritional factors}

The study of the effect of combinations of nutritional factors for the enhancement of bio-control traits by Pf CHAO was carried out by using Stat ease 8. For seven factors, a total of 16 combinations were used (Table 1). Each column has equal number of high and low values of given nutrient factor. $50 \mathrm{ml}$ of all the 16 media combination in $250 \mathrm{ml}$ conical flask was inoculated with $100 \mathrm{ul}$ of overnight grown bacterial and kept at $260 \mathrm{C}$ in shaking condition at $150 \mathrm{rpm}$ in darkness. After 2 day and 5 days, $20 \mathrm{ml}$ of bacterial was transferred in sterile 50 $\mathrm{ml}$ centrifuge tubes for metabolite extraction. Absorbance of the culture was noted at $600 \mathrm{~nm}$ to monitor the growth of the organism in the medium. $\mathrm{pH}$ of all media was in the range of 6.6 to 6.8 at time of inoculation and between 7.5 to 7.8 after 2 day and 5 day of growth.

Table 1: Growth and antifungal activity by Pf CHAO under different nutrient combinations.

\begin{tabular}{|c|c|c|c|c|c|c|c|}
\hline \multirow{3}{*}{ S.No. } & \multicolumn{3}{|c|}{ Variables } & \multicolumn{4}{|c|}{ Responses } \\
\hline & \multirow{2}{*}{ Nutrient combinations } & \multirow{2}{*}{$\begin{array}{c}\text { Nutrient } \\
\text { Combination } \\
\text { No.(by Stat ease } \\
\text { 8) }\end{array}$} & \multirow{2}{*}{$\begin{array}{l}\text { Supplemented }(\mathrm{mM}) \mathrm{C}: \\
\mathrm{N}: \mathrm{Pi}:(\mathrm{Fe}, \mathrm{Mo} \text { and } \mathrm{Zn}) \\
\text { ratio }\end{array}$} & \multicolumn{2}{|c|}{ Growth OD $\lambda_{600 \mathrm{~nm}}(\mathrm{AU})$} & \multicolumn{2}{|c|}{$\begin{array}{c}\text { Antifungal Activity } \\
(\%)\end{array}$} \\
\hline & & & & 2 day & 5 day & 2 day & 5 day \\
\hline 1 & Dilute NBY & 5 & $0: 0: 0: 0$ & 0.25 & 0.24 & 0 & 44.3 \\
\hline \multicolumn{8}{|c|}{ Dilute NBY supplemented with } \\
\hline 2 & $\mathrm{ZnSO}_{4}, \mathrm{KNO}_{3},\left(\mathrm{NH}_{4}\right)_{6} \mathrm{Mo}_{7} \mathrm{O}_{24}$ & 15 & $0: 10: 0: 0.35(\mathrm{Zn}): 0.5(\mathrm{Mo})$ & 0 & 0 & 0 & 0 \\
\hline 3 & $\mathrm{KH}_{2} \mathrm{PO}_{4}, \mathrm{KNO}_{3}, \mathrm{FeSO}_{4}$ & 8 & $0: 10: 10: 0.5(\mathrm{Fe})$ & 0.20 & 0.59 & 17 & 0 \\
\hline 4 & $\mathrm{ZnSO}_{4}, \mathrm{KH}_{2} \mathrm{PO}_{4},\left(\mathrm{NH}_{4}\right)_{6} \mathrm{Mo}_{7} \mathrm{O}_{2}, \mathrm{FeSO}_{4}$ & 10 & $\begin{array}{c}0: 0: 10: 0.5(\mathrm{Fe}): 0.35(\mathrm{Zn}): \\
0.5(\mathrm{Mo})\end{array}$ & 1.67 & 2.96 & 14.3 & 50 \\
\hline 5 & Citrate , $\mathrm{KH}_{2} \mathrm{PO}_{4}, \mathrm{KNO}_{3},\left(\mathrm{NH}_{4}\right)_{6} \mathrm{Mo}_{7} \mathrm{O}_{24}$ & 12 & 300:10:10:0.5(Mo) & 0.14 & 0.29 & 0 & 44.3 \\
\hline 6 & Citrate , $\mathrm{FeSO}_{4},\left(\mathrm{NH}_{4}\right)_{6} \mathrm{Mo}_{7} \mathrm{O}_{24}$ & 7 & $300: 0: 0: 0.5(\mathrm{Fe}): 0.5(\mathrm{Mo})$ & 0.22 & 0.14 & 0 & 10.7 \\
\hline 7 & Citrate , $\mathrm{KH}_{2} \mathrm{PO}_{4}, \mathrm{ZnSO}_{4}$ & 3 & 300:0:10:0.35(Zn) & 0.28 & 0.29 & 5.8 & 0 \\
\hline 8 & Citrate $, \mathrm{KNO}_{3}, \mathrm{FeSO}_{4}, \mathrm{ZnSO}_{4}$ & 9 & $\begin{array}{l}300: 10: 0: 0.5(\mathrm{Fe}) \\
\quad: 0.35(\mathrm{Zn})\end{array}$ & 5.24 & 2.40 & 11 & 70.7 \\
\hline 9 & Glucose, $\mathrm{ZnSO}_{4}, \mathrm{FeSO}_{4}$ & 4 & $600: 0: 0: 0.5(\mathrm{Fe}): 0.35(\mathrm{Zn})$ & 0.18 & 0.08 & 0 & 18.6 \\
\hline 10 & Glucose, $\mathrm{KH}_{2} \mathrm{PO}_{4^{\prime}}(\mathrm{NH} 4) 6 \mathrm{Mo} 7024$ & 2 & 600:0:10:0.5(Mo) & 0.22 & 0.18 & 10.7 & 10.7 \\
\hline 11 & Glucose, $\mathrm{KNO} 3,\left(\mathrm{NH}_{4}\right)_{6} \mathrm{Mo}_{7} \mathrm{O}_{24}, \mathrm{FeSO}_{4}$ & 14 & $\begin{array}{l}600: 10: 0: 0.5(\mathrm{Fe}) \\
\quad: 0.5(\mathrm{Mo})\end{array}$ & 0.24 & 0.26 & 18.7 & 30 \\
\hline 12 & Glucose, $\mathrm{KH}_{2} \mathrm{PO}_{4}, \mathrm{KNO}_{3}, \mathrm{ZnSO}_{4}$ & 6 & $600: 10: 10: 0.35(\mathrm{Zn})$ & 4.04 & 3.73 & 0 & 0 \\
\hline 13 & Citrate ,Glucose, $\mathrm{KH}_{2} \mathrm{PO}_{4}, \mathrm{FeSO}_{4}$ & 1 & $900: 0: 10: 0.5(\mathrm{Fe})$ & 3.48 & 3.04 & 10.7 & 70.7 \\
\hline 14 & Citrate ,Glucose, $\mathrm{KNO}_{3}$ & 13 & $900: 10: 0: 0$ & 4.53 & 2.83 & 61 & 38.6 \\
\hline 15 & Citrate ,Glucose, $\mathrm{ZnSO}_{4},(\mathrm{NH} 4)_{6} \mathrm{Mo}_{7} \mathrm{O}_{24}$ & 11 & 900:0:0:0.35(Zn): & 4.61 & 2.83 & 44.3 & 64.3 \\
\hline 16 & $\begin{array}{l}\text { Citrate ,Glucose, } \mathrm{ZnSO}_{4}, \mathrm{KH}_{2} \mathrm{PO}_{4} \\
\mathrm{KNO}_{3},\left(\mathrm{NH}_{4}\right)_{6} \mathrm{Mo}_{7} \mathrm{O}_{24}, \mathrm{FeSO}_{4}\end{array}$ & 16 & 900:10:10:0.5(Fe): & 4.58 & 2.76 & 47 & 70.7 \\
\hline
\end{tabular}

\section{Extraction, identification and quantification of antifungal metabolites}

Antibiotics were extracted from bacterial supernatants and quantified with high-performance liquid chromatography (HPLC, Shimadzu 10) as described by Duffy and Defago, 1997. Metabolites were identified and by comparison with the pure
DAPG, PRN and PLT. Metabolite quantity was estimated from standard curves of reference compounds and normalized for the bacterial absorbance at $600 \mathrm{~nm}$ prior to extraction. Briefly, liquid culture of $20 \mathrm{ml}$ were acidified to $\mathrm{pH} 2$ with 400 to $700 \mu \mathrm{l}$ of 1 $\mathrm{N} \mathrm{HCl}$ and extracted with $20 \mathrm{ml}$ of ethyl acetate for $60 \mathrm{~min}$ with vigorous shaking at $200 \mathrm{rpm}$. Phase separation was accelerated 
by $15 \mathrm{~min}$ of centrifugation at $5000 \mathrm{rpm}$. The organic phase was transferred to a round-bottomed glass flask flash evaporated, and the residue was dissolved in $1 \mathrm{ml}$ of HPLC-grade methanol and quantified by established HPLC procedures Keel et al. (1992); Maurhofer et al. (1992)[24].

\section{In vitro tests of fungal antagonism}

The plate test screening for in vitro antagonism against the plant-pathogenic fungus Rhizoctonia bataticola was performed by placing an agar plug with in the centre of a Potato Dextrose Agar (Hi-media, Mumbai, India) plate and by adding $100 \mu$ l ethyl acetate extract in the well bored at four places equidistance from centre at plate periphery. The plates were incubated at $30^{\circ} \mathrm{C}$ for fungal growth and checked for zones of mycelia growth inhibition after approximately 2 and 5 days, when the fungal mycelium had reached the edge of the plate. Percentage of fungal inhibition was calculated as: radial growth of fungus from centre -radial growth of fungus in presence of extract)/radial growths of fungus from centre X 100. All tests were performed 4 times, with new extract used each time.

\section{Principal Component Analysis}

PCA was used to establish combinations of variables e.g $\mathrm{OD}_{600 \mathrm{~nm}}, \mathrm{PRN}, \mathrm{DAPG}$ and PLT biosynthesis to describe the principal tendencies. PCA study provided the corresponding Eigen values, which were extracted by each factor, and the variance percentages (accounted for and accumulative) corresponding to the principal components by formula $\mathrm{Fn}=\mathrm{A} 1$ $\mathrm{X} 1+\mathrm{A} 2 \mathrm{X} 2+\ldots+\mathrm{An} \mathrm{Xn}$. Given $X$ observations on $n$ variables, PCA reduce the dimensionality of the data matrix by finding $r$ new variables, where $r$ is less than $n$. PCA Analysis revealed that data can be summarizing with just five variables and it contains all 5 principal components and their corresponding Eigen values for 2 day and 5 day.

\section{Seed sterilization and plant inoculation study}

Equal sized seeds Vigna radiata were thoroughly washed 3-4 times by sterile distilled water and treated with $1 \% \mathrm{HgCl}_{2}$ for 2 minute followed by 2 minute treatment of $70 \%$ ethanol with vigorously shaking. Then the seeds were given two or three washes of sterile distilled water and were transferred to sterile petriplates containing wet filter paper. The seeds were incubated in dark. Sterile distil water was again added on the second day to maintain humidity for proper germination. Seeds were germinated up to the time when radical size reached to 1 $\mathrm{cm}$. Overnight grown bacterial culture were used to inoculate germinated sterile seedlings of Vigna radiata. The germinated seedlings were incubated in saline washed bacterial suspension for 30 minutes and then three seedlings were planted in $75 \mathrm{ml}$ Murashige and Skoog medium with in $500 \mathrm{ml}$ glass tube (HiMedia Ltd, India) and the various supplementations according to different combination types containing $0.7 \%$ agar. The seedlings were allowed to grow for 7 days at $30 \pm 2{ }^{\circ} \mathrm{C}$ in alternate dark and light period.

\section{Plant protection assay}

For the in vitro antifungal assay MS medium was supplemented with biocontrol supportive combinations. The germinated seedlings were incubated in saline washed bacterial suspension for 30 minutes. After bacterial treatment seedling were treated with fungal broth aliquot from same stock broth of grown fungus in potato dextrose broth. Three seedlings were planted in $75 \mathrm{ml}$ Murashige and Skoog medium with in $500 \mathrm{ml}$ glass tube (Hi-Media Ltd, India) and the various supplementations according to different combination types containing $0.7 \%$ agar. The seedlings were allowed to grow for 7 days at $30 \pm 2{ }^{\circ} \mathrm{C}$ in alternate dark and light period.

\section{Results and Discussion}

\section{Effect of nutrient combinations on growth and antifungal activity}

Numerous biotic and abiotic signals influence the production of antifungal compounds, including different mineral and carbon sources as well as metabolites released by micro-organisms and plants [27-29]. Quantitative and/or qualitative differences in the sugar, nitrogen, phosphate and mineral component of root exudates could determine the optimal environment for the effective bio-control mechanism in given crop-pathogen systems $[24,30]$. Our results add another point to plant specificity i.e. the influence of combination of root exudates components and edaphic factors on the growth, biocontrol traits and biosynthesis of antimicrobial metabolites by fluorescent Pseudomonas which will be helpful to increase its competence and survival efficiency in rhizosphere.

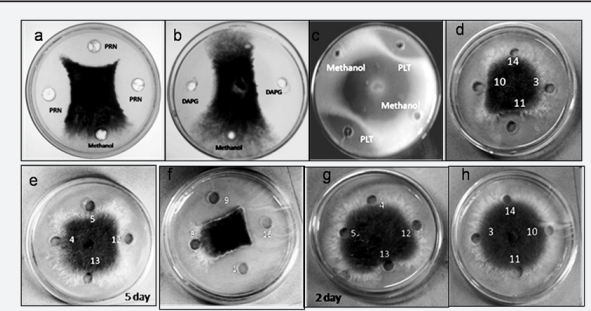

Figure 1: Inhibition of $R$. bataticola by ethyl acetate extract of Pf $\mathrm{CHAO}$ grown in various combinations; Inhibition of $\mathrm{R}$. bataticola by (a) PRN; (b)DAPG; (c)PLT; (d-f) 5 day ethyl acetate extract; $(\mathrm{g} \& \mathrm{~h}) 2$ day ethyl acetate extract.

Use of 1/5-strength nutrient broth yeast extract broth only and further amendment with different combinations of glucose, citrate, $\mathrm{KNO}_{3}, \mathrm{KH}_{2} \mathrm{PO}_{4}, \mathrm{FeSO}_{4}, \mathrm{ZnSO}_{4}$, and $\left(\mathrm{NH}_{4}\right)_{6} \mathrm{Mo}_{7} \mathrm{O}_{24}$ resulted into the variations in $\mathrm{Pf}$ CHAO response for the growth , antifungal activity and antibiotics productions. Effect of nutrient combinations on 2 day growth $(p=0.0026)$ and 5 day growth $(\mathrm{p}=0.011)$ and antifungal activity by the 2 day $(p=0.0082)$ and 5 day $(p=0.0007)$ ethyl acetate extract for the antibiotics from different nutrient combinations have shown significant variations (Table 1). The inhibition of R.bataticola by the ethyl acetate extract of different nutrient combinations is shown in (Figure 1). Combination amended with KNO3, 
$\left(\mathrm{NH}_{4}\right)_{6} \mathrm{Mo}_{7} \mathrm{O}_{24}$ and $\mathrm{ZnSO}_{4}$ did not supported the Pf CHA0 growth. Combination amended with citrate, $\mathrm{FeSO} 4$, glucose and $\mathrm{KH}_{2} \mathrm{PO}_{4}$ combination amended with citrate , $\mathrm{FeSO}_{4}, \mathrm{KNO}_{3}$ and $\mathrm{ZnSO}_{4}$ and the combination amended with citrate glucose, $\mathrm{FeSO} 4, \mathrm{KH}_{2} \mathrm{PO}_{4}$, $\mathrm{KNO}_{3},\left(\mathrm{NH}_{4}\right)_{6} \mathrm{Mo}_{7} \mathrm{O}_{24}$ and $\mathrm{ZnSO}_{4}$ have shown highest antifungal activity of $70 \%$ on 5 day and high growth( $\mathrm{OD}_{600 \mathrm{~nm}}=3 \pm 0.5$ ). Combination amended with citrate, FeSO4, glucose and KH2PO4 and combination amended with glucose, KH2PO4, KNO3 and ZnSO4 has supported growth on both the days of sampling with OD $600 \mathrm{~nm}$ value of $4 \pm 0.5$ but earlier combination supported more to antifungal activity on 5 day.

Combination amended only with all inorganic components viz., $\mathrm{FeSO}_{4}, \mathrm{KH}_{2} \mathrm{PO}_{4},\left(\mathrm{NH}_{4}\right)_{6} \mathrm{Mo}_{7} \mathrm{O}_{2}$, and $\mathrm{ZnSO}_{4}$ showed green fluorescent pigment biosynthesis and antifungal activity up to $40 \%$ on 5 day. Combination with $\mathrm{Zn}$, Mo and nitrate only did not support growth because of very low $\mathrm{C} / \mathrm{N}$ ratio $(\mathrm{C} / \mathrm{N}<1)$ and the stress effect of heavy metal $\mathrm{Zn}^{2+}$ and $\mathrm{Mo}^{2+}$ and it was not included in the further data analysis and graphs. Combination supplemented with glucose, citrate, $\mathrm{Zn}^{+}$and $\mathrm{Mo}^{2+}$ supported well to growth and showed declined growth on 5 day due to low nitrogen content but good antifungal activity on 2 day and 5 day due to very high $\mathrm{C} / \mathrm{N}$ ratio. The amount of available nitrogen seems to be the crucial factor in deciding the metabolic response especially under $\mathrm{N}$ - limitation. Most the pathways used for $\mathrm{N}$ assimilation under N- limitation utilize high amount of ATP.

Therefore, it appears critical for the cell to shut down activities of such pathways under certain circumstances to save ATP which causes the cell concentration decreases [33]. Combination without any amendments showed low growth but high antifungal activity on 5 day than on 2 day which suggest that in diluted nutrient broth even growth is low and not much difference in 2 and 5 day growth but antifungal trait get induced on 5 day which indicates that as bacterial ages antifungal traits get intensified and such trend should be followed in every combinations and this combination should be considered as negative control for the amendments. Kumar and Shimizu 2010 reported that, as $\mathrm{C} / \mathrm{N}$ ratio increases the transcript level of $\mathrm{rpoN}$ get increased, which encodes $\sigma^{54}$. So the induction of rpoN was thought to be possible reason for the induced antifungal traits.

Effect of nutritional factors and their contribution to growth of Pf CHAO at 2 day and 5 day is depicted in (Figure 2). Citrate, glucose, $\mathrm{Zn}^{2+}$, citrate and glucose and triple combination of citrate, glucose and nitrate have shown positive effect on growth. Citrate and $\mathrm{Pi}$, citrate and zinc, $\mathrm{Mo}^{2+}$, citrate and $\mathrm{Mo}^{2+}$, triple combination of citrate, glucose and $\mathrm{KNO}_{3}$ have shown negative effects on growth (Figure 2). Citrate and Pi individually have shown positive effect and contribution of $9 \%$ and $5 \%$ respectively on 2 day and $10 \%$ and $1 \%$ respectively on 5 day however the combination of citrate and Pi showed negative effect on growth and contributed to $18 \%$ on 2 day and $19 \%$ on 5 day. Contribution order of the factors acting positively on the 2 day growth is, Glucose $>\mathrm{Zn}^{2+}>$ citrate +glucose $>$ citrate $>\mathrm{Pi}>\mathrm{KNO}_{3}$ while for the 5 day growth the order is $\mathrm{Zn}^{2+}>$ citrate + glucose $>$ citrate $>$ glucose $>\mathrm{Pi}=\mathrm{KNO}_{3}$. In our result, citrate and glucose individually and in combination, have shown strong positive effect on $P f$ CHA0 growth on 2 day and 5 day which is in accordance to previous finding that an organic acid or a tricarboxylic acid cycle intermediate, not glucose, is usually the preferred carbon source in Pseudomonas species [34]. Of the minerals, zinc was found to be supportive much to Pf CHA0 growth on 2 day and 5 days. Sodeberg et al. (1990) explained that the zinc exhibits different bacterial affinity with gram-positive and gram-negative bacteria, it may be ascribed to the difference in the protein constituents of their cell walls zinc and other minerals are essential for growth, they influence cell membrane integrity, and they are key components and/or catalysts of over 300 enzymes and other proteins [35].

However the contribution order of negatively acting factors on 2 day growth is, citrate $+\mathrm{Pi}=$ Citrate + glucose $+\mathrm{KNO} 3>\mathrm{Mo} 2+$ and for 5 day growth order is, citrate $+\mathrm{Pi}>$ citrate +glucose + KNO3 >citrate $+\mathrm{Zn} 2+$. Ammonium molybdate has been reported to be a strong inhibitor of acid phosphatase activity [36] and the process of phosphorylation / dephosphorylation plays a crucial role in many metabolic processes [37].

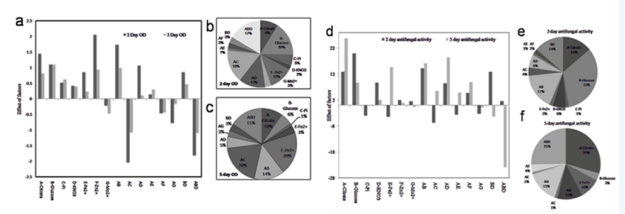

Figure 2: Effect of nutritional factors and their contribution to Pf CHAO growth and antifungal activity; (a) Effect of factors on 2 day and 5 day OD $600 \mathrm{~nm}$; (b\& c)contribution of factors to the effect on 2 day and 5 day OD $600 \mathrm{~nm}$; (d) Effect of factors on 2 day and 5 day antifungal activity; (e\&f) contribution of factors to the effect on 2 day and 5 day antifungal activity.

Effect of nutritional factors and their contribution to 2 day and 5 day antifungal activity shown in Figure 2. Citrate has strong positive effect on antifungal activity on 5 day and contribution $29 \%$ and 2 day with contribution $14 \%$. However glucose showed more positive effect on 2 day than 5 day with contribution $33 \%$ on 2 day and only $3 \%$ on 5 day. Citrate with glucose has positive effect and shown $16 \%$ contribution on 2 day and $12 \%$ on 5 day (Figure 2). Although carbon sources differentially influence medium acidification during growth [38], which may then indirectly affect antibiotic biosynthesis [39] and bio control activity [9] but in our result we did not observe any significant change medium $\mathrm{pH}$ after 2 day and 5 day of growth. On 2 day, $\mathrm{Pi}$, $\mathrm{Fe} 2+$, Citrate with $\mathrm{Pi}$, citrate with $\mathrm{Fe} 2+$ and citrate with $\mathrm{Mo} 2+$ have shown negative effect on antifungal activity. On 5 day only glucose with nitrate and citrate with glucose and nitrate have shown negative effect on antifungal activity. Glucose with nitrate contributed $14 \%$ on 2 day and only $1 \%$ on 5 day. Citrate with nitrate contributed $6 \%$ on 2 day to $15 \%$ on 5 day. Contribution of triple combination of citrate, glucose and nitrate was $25 \%$ on 
5 day but no contribution on 2 day. Citrate with nitrate showed $6 \%$ contribution on 2 day and $15 \%$ on 5 day.

Contribution order of factors acting positively to antifungal activity on 2 day is, Glucose>citrate>citrate +glucose while on 5 day antifungal activity the order is, citrate> citrate + glucose $>\mathrm{Fe}^{2+}>$ glucose $>$ citrate $+\mathrm{Pi}=$ citrate $+\mathrm{Fe}^{2+}$. Combination with $\mathrm{Fe}^{2+}$ and citrate have shown increased antifungal activity on 5 day and was thought to be mediated by induction of antifungal traits specifically. It is in support of previous observation that iron stimulates bicontrol activity [13] and cyanide production [2]. However the antifungal activity on 2 day is negatively regulated in following order, Citrate $+\mathrm{Pi}>$ citrate +glucose + $\mathrm{KNO}_{3}>>$ citrate $+\mathrm{Fe}^{2+}$ and on 5 day in the order citrate + glucose $+\mathrm{KNO}_{3}>$ citrate $+\mathrm{KNO}_{3}>$ glucose $+\mathrm{KNO}_{3}>\mathrm{Pi}=\mathrm{KNO}_{3}$. Glucose and citrate individually and in combinations, supported well to growth and antifungal activity. Combination with mineral supplementation of $\mathrm{Fe}^{2+}, \mathrm{Mo}^{2+}, \mathrm{Zn}^{2+}$ and $\mathrm{Pi}$ showed pigmentation after 5 day of growth and $40 \%$ antifungal activity and thought to positive effect of $\mathrm{Pi}$ on growth and positive effect of $\mathrm{Fe}^{2+}$ on antifungal traits. Combination with glucose, citrate and nitrate and did not have any amended mineral nutrient and have shown more growth ( 2 day OD600 $\mathrm{nm}>4.0$ ) and antifungal activity on 2 day and less growth (OD600nm 5 day $>3$ ) and antifungal activity on 5 day which could be possible due to high $\mathrm{C} / \mathrm{N}$ ratio which will induce rpoN and also antifungal traits and have not any interference of heavy metals.

Combination with $\mathrm{Fe}^{2+}$, nitrate and phosphate showed weak growth and antifungal activity which could be possible due to very low $\mathrm{C} / \mathrm{N}$ ratio but only low growth because of supplementation of $\mathrm{Pi}$ and $\mathrm{Fe}^{2+}$. Effect of factors on antifungal activity showed many variations in effect (+/-) and contribution compare to its effect on growth. Possible reason could be that the growth is result of basic metabolism and cumulative effect of many supportive pathways but antifungal activity is contributed by limited number of pathways so the variation in effect was observed. Citrate and Pi individually have positive effect on the growth but their combination have shown negative effect which show a kind of the shift of bacterial physiology/behaviour to nutrients present individually and in combinations.'

\section{Effect on nutritional factors on antibiotic biosynthesis}

PRN biosynthesis under different nutrient combinations is depicted in Table 2. Significant variation in biosynthesis level of PRN was observed across all combinations on 2 day $(p=0.0016)$ and 5 day $(p=0.0045)$. Nutrient combination amended with $\mathrm{FeSO} 4, \mathrm{KH} 2 \mathrm{PO} 4$ and $\mathrm{KNO} 3$, combination amended with,KH2PO4, (NH4)6Mo7O2, FeSO4 and ZnSO4, combination amended with FeSO4, Glucose, KNO3 and (NH4)6Mo7O24, and combination amended with citrate, FeSO4, glucose, KH2PO4, KNO3, (NH4)6Mo7024 and ZnSO4 supported PRN biosynthesis on 2 day.Nutrient combination amended with citrate, FeSO4, glucose and $\mathrm{KH} 2 \mathrm{PO}$, combination amended with citrate,FeSO4, KNO3 and ZnSO4, combination amended with citrate, FeSO4, glucose, KH2PO4, KNO3, (NH4)6Mo7O24 and ZnSO4, combination amended with citrate,glucose,(NH4)6Mo7024 and ZnSO4 and combination amended with citrate, KH2PO4, KNO3 and (NH4)6Mo7024 supported PRN biosynthesis on 5 day. It supports the previous observation by Duffy and Defago, 1999 that the production of pyrrolnitrin by Pf CHAO was stimulated by $\mathrm{Mo}^{2+}$.

Table 2: Biosynthesis of PRN,DAPG and PLT under different nutrient combinations.

\begin{tabular}{|c|c|c|c|c|c|c|c|}
\hline \multirow{3}{*}{ S. No. } & \multirow{3}{*}{$\begin{array}{l}\text { Variables } \\
\text { Supplemented (mM)-C : N : Pi : } \\
\text { Minerals (Fe, Mo and } \mathrm{Zn}) \text { ratio }\end{array}$} & \multicolumn{6}{|c|}{ Responses } \\
\hline & & \multicolumn{2}{|c|}{ PRN production (ng/ml) } & \multicolumn{2}{|c|}{$\begin{array}{l}\text { DAPG production (ng/ } \\
\mathrm{ml} \text { ) }\end{array}$} & \multicolumn{2}{|c|}{ PLT production $(\mathrm{ng} / \mathrm{ml})$} \\
\hline & & 2 day & 5 day & 2 day & 5 day & 2 day & 5 day \\
\hline 1 & 0:0:0:0 & 411 & 29.5 & 26 & 33.3 & 60 & 6590 \\
\hline 2 & $0: 10: 0: 0.35(\mathrm{Zn}): 0.5(\mathrm{Mo})$ & 0.00 & 0.00 & 0.0 & 0.00 & 0.00 & 0.00 \\
\hline 3 & $0: 10: 10: 0.5(\mathrm{Fe})$ & 1375 & 4 & 26.5 & 22.65 & 695 & 90 \\
\hline 4 & $0: 0: 10: 0.5(\mathrm{Fe}): 0.35(\mathrm{Zn}): 0.5(\mathrm{Mo})$ & 1710 & 70 & 82 & 20 & 1488 & 7285 \\
\hline 5 & 300:10:10:0.5(Mo) & 87 & 1046 & 25 & 80.45 & 49.35 & 238 \\
\hline 6 & 300:0:0:0.5(Fe):0.5(Mo) & 28.5 & 574 & 21 & 56.95 & 25 & 57 \\
\hline 7 & 300:0:10:0.35(Zn) & 105 & 5 & 83.5 & 29.9 & 23 & 142.5 \\
\hline 8 & $300: 10: 0: 0.5(\mathrm{Fe}): 0.35(\mathrm{Zn})$ & 565 & 2012.5 & 17.5 & 153.5 & 117 & 1121 \\
\hline
\end{tabular}


Advances in Biotechnology \& Microbiology

\begin{tabular}{|c|c|c|c|c|c|c|c|}
\hline 9 & 600:0:0:0.5(Fe):0.35(Zn) & 29.5 & 609 & 54.5 & 0 & 21 & 203.5 \\
\hline 10 & 600:0:10:0.5(Mo) & 0.00 & 0.00 & 32 & 26 & 0 & 43.5 \\
\hline 11 & $600: 10: 0: 0.5(\mathrm{Fe}): 0.5(\mathrm{Mo})$ & 1045 & 120 & 317.5 & 1241.5 & 117 & 794.5 \\
\hline 12 & 600:10:10:0.35(Zn) & 402 & 4 & 85.5 & 0 & 32 & 44.5 \\
\hline 13 & $900: 0: 10: 0.5(\mathrm{Fe})$ & 555 & 1370.5 & 8.5 & 126.25 & 66 & 1991 \\
\hline 14 & 900:10:0:0 & 675 & 306 & 13 & 321.5 & 2193 & 2493 \\
\hline 15 & 900:0:0:0.35(Zn): 0.5(Mo) & 87.5 & 930 & 107.5 & 17 & 1875 & 3388 \\
\hline 16 & $\begin{array}{c}900: 10: 10: 0.5(\mathrm{Fe}): \\
0.35(\mathrm{Zn}): 0.5(\mathrm{Mo})\end{array}$ & 870 & 1014 & 99.5 & 23.5 & 1229 & 2893 \\
\hline
\end{tabular}

It suggests that direct improvement in the bio control effectiveness by NH4-Mo could be indirectly mediated by altered enzymatic activity. Effect of nutritional factors and their contributions to PRN biosynthesis is depicted in Figure 3. $\mathrm{Fe} 2+, \mathrm{Pi}$, citrate with glucose and triple combination of nitrate, glucose with nitrate showed positive effect on PRN biosynthesis on 2 day. On 5 day, PRN biosynthesis is primarily influenced by citrate. Fe2+ showed strong positive effect on PRN biosynthesis with contribution $29 \%$ on 2 day and $13 \%$ on 5 day PRN biosynthesis. It is in support of previous observation that iron stimulates biosynthesis of a variety of antifungal metabolites (e.g., zwittermycin A [11], kanosamine [12], phenazine [13]).

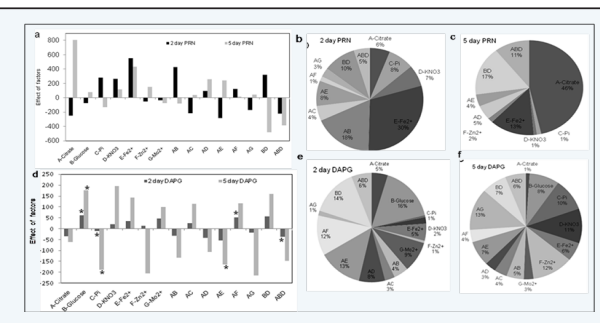

Figure 3: Effect of nutritional factors and their contribution to PRN and DAPG biosynthesis; (a) Effect of factors to PRN biosynthesis; (b\&c) Percent contribution of each of factors and its various combination to the effect on 2 day and 5 day PRN biosynthesis; (d) Effect of factors to DAPG biosynthesis; (e\&f) Percent contribution of each of factors and its various combination to the effect on 2 day and 5 day DAPG biosynthesis . ${ }^{*}(p<0.05)$.

Pi showed positive effect with $8 \%$ contribution on 2 day but negative effect with $1 \%$ contribution on 5 day PRN biosynthesis which is not significant effect and supports the previous finding that Pyrrolnitrin production by Pf CHAO was not affected by $200 \mathrm{mM}$ phosphate [16]. Contribution order of factors acting positively to PRN biosynthesis on 2 day is, $\mathrm{Fe} 2+>$ citrate + glucose $>$ glucose $+\mathrm{KNO} 3>\mathrm{Pi}>\mathrm{KNO} 3>$ citrate $+\mathrm{Pi}$ while on 5 day PRN biosynthesis the order is, Citrate $>\mathrm{Fe}^{2+}>$ citrate $+\mathrm{KNO}>$ citrate $+\mathrm{Fe}^{2+}>\mathrm{Zn}^{2+}>\mathrm{KNO}_{3}=$ citrate $+\mathrm{Pi}$. The negative effect of factors on PRN biosynthesis on 2 day is in the order, Citrate + glucose + KNO3 $>$ Citrate $+\mathrm{Fe} 2+>$ citrate $>\mathrm{Zn} 2+$ and on 5 day in the order, glucose $+\mathrm{KNO} 3>$ citrate + glucose $+\mathrm{KNO} 3>\mathrm{Pi}>$ Citrate +glucose.

The DAPG biosynthesis levels under different nutrient combinations are shown in Table 2. DAPG biosynthesis varies significantly in all 15 combinations on the 2 day $(\mathrm{p}=0.009)$ but non significantly on 5 day $(\mathrm{p}=0.10)$. Glucose, citrate with $\mathrm{Fe}^{2+}$, citrate with $\mathrm{Zn}^{2+}$ and triple combination of citrate, glucose and nitrate have shown significantly positive effect on DAPG biosynthesis at 2 day $(\mathrm{p}<0.05)$. The effect of nutrients on the DAPG biosynthesis on 2 day and 5 day depicted in Figure 3. Positive contribution of factors acting on DAPG biosynthesis on 2 day follows the order, glucose $>$ citrate $+\mathrm{Zn}^{2+}$.

DAPG biosynthesis on 2 day is stimulated by glucose followed by combination of citrate and $\mathrm{Zn} 2+$ confirming the previous observation that increased DAPG biosynthesis by glucose [16]. However the negatively acting factors on DAPG biosynthesis on 2 day follow the order, citrate $+\mathrm{Fe} 2+>$ citrate + glucose + KNO3. On 5 day DAPG is repressed by $\mathrm{Pi}$ which supports previous observation that DAPG production by Pf CHAO was almost abolished by $10 \mathrm{mM}$ phosphate. Growth was increased 5- to 10fold by $100 \mathrm{mM}$ phosphate amendment [16].

The biosynthesis level of PLT under different nutrient combinations shown in Table 2. PLT biosynthesis level varies significantly in all 15 combinations on the 2 day $(p=0.020)$ and 5 day $(\mathrm{p}=0.0098)$. PLT biosynthesis level was high in combination in FeSO4, KH2PO4, (NH4)6Mo7O2, and ZnSO4, combination amended with citrate, glucose, (NH4)6Mo7024 and $\mathrm{ZnSO4}$, combination amended with citrate ,glucose, and KNO3 and combination amended with citrate, FeSO4 ,glucose, KH2PO4, KNO3, (NH4)6Mo7O24 and ZnSO4 on 2 day. High PLT biosynthesis on 5 day was observed in the combination amended with citrate, $\mathrm{FeSO} 4$, glucose and $\mathrm{KH} 2 \mathrm{PO} 4$, combination amended with ZnSO4, KH2PO4, (NH4)6Mo7024, FeSO4 and 
combination amended with citrate, FeSO4, glucose, KH2PO4, KNO3, (NH4)6Mo7024 and ZnSO4 (Table 2). Table 2 shows the significant effect of nutritional factors and their combinations on PLT biosynthesis $(\mathrm{p}<0.05)$. Zinc increased PLT biosynthesis confirming the previous finding of Duffy and Defago, 1999 that zinc increased PLT biosynthesis in all fluorescent Pseudomonas strains able to produce this antibiotic, but the level of stimulation varied.

Citrate, glucose and combination of citrate with glucose showed positive effect on 2 day PLT biosynthesis and combination of citrate with glucose and citrate with nitrate and glucose with nitrate showed positive effect on 5 day PLT biosynthesis. Citrate with glucose contributed $37 \%$, citrate with Pi contributed to $18 \%$, citrate with $\mathrm{Fe} 2+$ contributed to $18 \%$ and citrate, glucose individually contributed to only $7 \%$ on 2 day PLT biosynthesis. For the 5 day, citrate with glucose, citrate with nitrate and glucose with nitrate has shown strong positive effect on PLT biosynthesis. Positive contribution of factors on PLT biosynthesis on 2 day showed following order, citrate+ glucose> glucose $=$ citrate $>$ glucose $+\mathrm{KNO} 3>$ citrate $+\mathrm{KNO} 3$ while on 5 day PLT biosynthesis the order is, citrate +glucose $>$ citrate+KNO3 > glucose+KNO3.

The negatively acting factors on PLT biosynthesis on 2 day showed the order, citrate $+\mathrm{Fe} 2+=$ Citrate $+\mathrm{Pi}>>$ citrate + glucose $+\mathrm{KNO} 3$ and on 5 day in the order citrate+ glucose $+\mathrm{KNO}>$ KNO3 $>>$ glucose $>$ citrate. PLT biosynthesis is maximally repressed by combination of citrate and $\mathrm{Fe} 2+$, citrate and phosphate on 2 day confirming the previous observation, that production of PLT by Pf CHA0 was completely inhibited by 100 $\mathrm{mM}$ but only slightly reduced by $10 \mathrm{mM}$ phosphate. However on 5 day PLT biosynthesis is maximum repressed by triple combination of citrate, glucose and nitrate followed by nitrate confirming the previous finding that PLT is repressed by glucose [16].

Combination of citrate and glucose has shown positive effect on 2 day and 5 day antifungal activity and well correlated by its positive effect on PRN and PLT production. Glucose showed the positive effect on 2 day antifungal activity and was correlated with its positive effect on DAPG production. Combination of citrate and $\mathrm{Fe} 2+$ has shown negative effect on 2 day antifungal activity and it was supported well by negative effect of this combination on 2 day PRN, DAPG and PLT production. Citrate has shown positive effect on 5 day antifungal activity and correlated with its positive effect on 5 day PRN production. Triple combination of citrate, glucose and nitrate has negative effect on antifungal activity and correlated also with its negative effect on PRN and PLT production. The importance of nutrient status to pyoluteorin production is corroborated by the observation that pyrrolquinoline quinone, a cofactor required by glucose and alcohol dehydrogenases, represses pyoluteorin production confirm that pyoluteorin production is linked to the physiological status of the cell [40].
In case of Pf-5 as bacterial ages, the stationary phase and stress response sigma factor RpoS $(\sigma S)$ and Lon protease, are implicated in regulation of antibiotic production. Relative levels of $\sigma S$ and the housekeeping sigma factor RpoD ( $\sigma D$ ) influence pyoluteorin, 2, 4-diacetylphloroglucinol, and pyrrolnitrin production. Abundant $\sigma S$ is required for the production of pyrrolnitrin but is repressive to pyoluteorin and 2,4 -diacetylphloroglucinol production $[25,26]$. So the role of relative levels of $\sigma S$ and the housekeeping sigma factor RpoD $(\sigma D)$ in the increased antifungal trait on 5 day in low/moderate growth supporting combinations could not be ignored.

\section{Contribution of PRN,DAPG and PLT for antifungal activity}

Based on antifungal activity under all combinations and the biosynthesis level of antifungal metabolites, the percentage contribution of PRN,DAPG and PLT to 2 day and 5 day antifungal activity by Pf CHAO depicted in Figure 4. For the 2 day antifungal activity, PLT has contributed 59\%,PRN has contributed $26 \%$ and remaining $15 \%$ by DAPG. For the 5 day antifungal activity PRN has contributed 59\%,PLT $37 \%$ and DAPG only $4 \%$. Regulation of DAPG and PLT production in Pf CHA0 involves a molecular balance in which each antibiotic induces the expression of its own biosynthetic genes while repressing the expression of the biosynthetic genes of the other antibiotic $[41,42]$. This could be possible reason of not obtaining significant variations in DAPG production under different nutrient combinations on day 5 and day 2. Another possible explanation for these deviations is that other, yet unknown effectors could interfere with the fine-tuned regulation of the DAPG-PLT balance. Similar deviation in DAPG production was obtained by Baehler et al. [41] as they have used GFP-based reporters to study the antibiotic gene expression at the transcriptional level. The possibility of involvement of some post-transcriptional regulatory mechanisms such as those controlled by the GacS/GacA two-component system Haas \& Keel (2003) may be involved in the modulation of the observed effects as well.

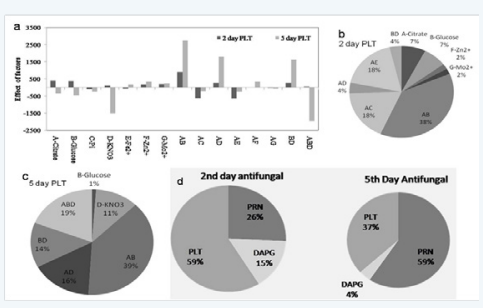

Figure 4: (a) Effect of factors to PLT biosynthesis; (b\&c) Percent contribution of each of factors and its various combination to the effect on 2 day and 5 day PLT biosynthesis; (d) Contributions of PRN, PHL and PLT to the 2 day and 5 day antifungal activity.

2 day antifungal found to have maximum positive correlation with PLT followed by PRN however both PLT and PRN itself had shown strong positive correlation with 0D600nm. Up to 2 day DAPG is found to be not dependent much on OD600nm and PLT. 5 day antifungal found to have maximum positive correlation 
with PRN followed by PLT however both PLT and PRN itself had shown a positive correlation with OD600nm. 5 day PLT have shown but negative correlation with DAPG production. 5 day DAPG have shown negative correlation with OD600nm, PRN and PLT which proves the earlier observation by Baehler et al. [41].

\section{Principal Component Aanalysis for 2 day and 5 day antifungal activity}

For the 2 day as biplot graph (Figure 5) as shown in that 2 day antifungal, OD and PLT biosynthesis showed strong correlation and fall in same zone $(-x,+y)$.While 2 day DAPG and PRN fall in other zone $(+x,+y)$. Based on PCA analysis for the five variables with sixteen different combinations, Pearson correlation between different variables was obtained (Figure 5) which shows the degree to which the variables are related with each other. Only the variables with the Pearson value (n) $\geq 0.35$ have been considered with significant relatedness between them. 2 day antifungal is positively correlation with PLT maximally ( $n=0.878)$ followed by OD ( $n=0.544)$, PRN and DAPG.2 day PRN has shown positively correlation with 2 day OD $(n=0.44)$, antifungal activity $(\mathrm{n}=0.38)$. DAPG is nearly independent of OD and PLT $(n<0.1) .2$ day PLT has shown high positive correlation with 0D600nm ( $\mathrm{n}=0.694)$ and antifungal activity.5 day antifungal activity have shown positive correlation with OD ( $\mathrm{n}=0.522)$, PRN $(n=0.768)$ and PLT $(n=0.475) .5$ day PLT have shown positive correlation with OD $(n=0.33)$ and antifungal activity $(n=0.475)$ but negative correlation with DAPG production $(n=-0.16)$. DAPG have shown negative correlation with OD $(n=-0.187), P R N(n=-$ 0.131) and PLT.

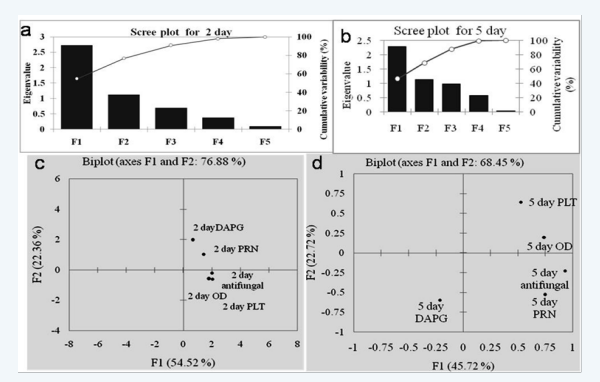

Figure 5: Principal Component Analysis,(a\&b) Screen plot for 2 day and 5 day, (c\&d) PCA biplot graph for 2 day and 5 day.

For 2 day the results showed that of the first three components, the first component accounted for about $54.52 \%$, the second component about $22.36 \%$ and the third component about $13.88 \%$ of the total variance in the data set These three components together accounted for about $90.71 \%$ of the total variance and the rest of the components only accounted for about 9.29\%.For 5 day biplot graph (Figure 5). shows that PLT and OD shows correlation and falls in same zone $(+x,+y)$ while 5 day antifungal and PRN falls in other zone $(+x,-y)$. For the 5 day PCA analysis first three components, the first component accounted for about $45.72 \%$, the second component about $22.72 \%$ and the third component about $19.44 \%$ of the total variance in the data set. These three components together accounted for about 87.89
$\%$ of the total variance and the rest of the components only accounted for about $12.11 \%$ (Figure 5).

\section{Plant protection assay}

The plant growth promoting effect of $P f$ CHAO on Vigna radiata under biocontrol trait supporting combinations has been shown in Figure 6. Combination with glucose, FeSO4, KNO3 and $\mathrm{ZnSO} 4$ supplemented to MS medium and combination with glucose,citrate, nitrate, $\mathrm{Pi}, \mathrm{ZnSO}_{4}, \mathrm{FeSO}_{4}$ and $\mathrm{Mo}^{2+}$ have shown inhibition of plant growth in compare to non supplemented combination while inhibitory effect was minimized in inoculated with Pf CHA0.Plant inoculation study for the antifungal activity of Pf CHAO under antifungal traits supportive combinations has been shown in Figure 6. Non supplemented combination supported to plant growth in uninoculated control and growth suppression in R.bataticola treated set. Pf CHAO have shown highest plant growth promotion out of all combination and MS medium control. Pf CHA0 showed an effective inhibition of R.bataticola and plant protection in combination supplemented with glucose, $\mathrm{FeSO}_{4}, \mathrm{KNO}_{3}$ and $\mathrm{ZnSO}_{4}$ supplemented to MS medium and combination with glucose, citrate, nitrate, $\mathrm{Pi}, \mathrm{ZnSO}_{4}$, $\mathrm{FeSO}_{4}$ and $\mathrm{Mo}^{2+}$ in compare to un-inoculated control.

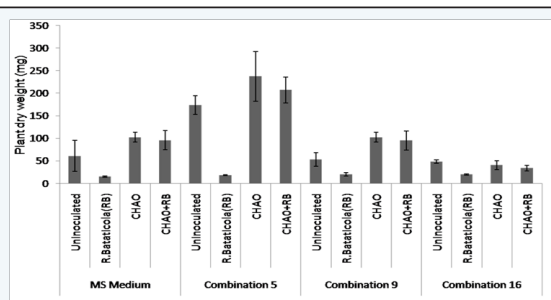

Figure 6: Bio control activity of $\mathrm{Pf} \mathrm{CHAO}$ for the protection of Vigna radiata from R.bataticola under bio-control supportive nutrient combinations. Combination 5 -Non amended with nutrients, Combination 9 - Citrate, $\mathrm{KNO}_{3}, \mathrm{FeSO}_{4}, \mathrm{ZnSO}_{4}$, combination 16 - Citrate, Glucose, $\mathrm{ZnSO}_{4}, \mathrm{H} 2 \mathrm{PO}_{4}, \mathrm{KNO}_{3}$, $\left(\mathrm{NH}_{4}\right)_{6} \mathrm{Mo}_{7} \mathrm{O}_{24}, \mathrm{FeSO}_{4}$.

In biocontrol supportive combination with Mo and $\mathrm{Zn}$ it could be deleterious effect of metals on plant growth which could be the possible reason of less growth in compare to non supplemented combination .Combination 16 have three metals so it has retorted the plant growth effectively in compare to combination 9 which have $\mathrm{Fe}^{2+}$ and $\mathrm{Zn}^{2+}$. Combination 9 retardation effect was minimized by $P f$ CHAO inoculation compare to uninoculated. In bio control supportive combination the effective suppression of R.bataticola by Pf CHA0 was observed. Non Supplemented combination have supported to plant growth in uninoculated control and bio control support against R.bataticola. Pf CHAO have shown highest plant growth promotion out of all combination and MS medium control. Possible reason could be that this combination does not have any metal which is inhibitory to plant growth and it is also supportive to Pf CHAO growth in compare to MS medium. Pf CHA0 showed effective bio-control against R.bataticola in bio control supporting combinations. 


\section{Conclusion}

Present work establish the connection between multiple combinations of nutrients and edapic factors relevant to root zone and its effect on the growth, antifungal activity and biosynthetic of pyrrolnitrin, 2, 4-DAPG and pyoluteorin by Pf CHA0. Result showed that citrate, glucose, combination of citrate and glucose, ferrous iron and zinc have positive effect on growth, antifungal activity and antibiotic biosynthesis. Triple combination of citrate, glucose and nitrate inhibited the growth, antifungal activity and antibiotic biosynthesis. Antifungal activity is maximum contributed by pyoluteorin initially but by pyrrolnitrin later stage of growth. Bio-control supporting nutrient combinations showed effective protection of Vigna radiata from $R$.bataticola infection in plant inoculation assay.

\section{Acknowledgement}

Authors express a gratefully acknowledgement to University Grant Commission-Research Fellowship for Meritorious Student (UGC-RFMS) and Gujarat State Biotech Mission (GSBTM), India, for the financial support.

\section{References}

1. Cook RJ (1993) Making greater use of introduced microorganisms for biological control of plant pathogens. Annu Rev Phytopathol 31: 53-80.

2. Keel C, Voisard C, Berling CH, Kahr G, Defago G (1989) Iron sufficiency, a prerequisite for the suppression of tobacco black root rot by Pseudomonas fluorescens strain $\mathrm{CHA} 0$ under gnotobiotic conditions. Phytopathology 79: 584-589.

3. Haas D, Defago G (2005) Biological control of soil-borne pathogens by fluorescent pseudomonads. Nat Rev Microbiol 3(4): 307-319.

4. Defago GC (1995) Pseudomonad as bio control agents of diseases caused by soil-borne pathogens. Pages 137-148 In: HMT Hokkanen, JM Lynch (Eds.), Benefits and Risks of Introducing Biocontrol Agents Cambridge University Press, England.

5. Lemanceau P, Alabouvette C (1993) Suppression of Fusarium wilts by fluorescent pseudomonads: Mechanisms and applications. Biocontrol Sci Technol. 3(3): 219-234.

6. Thomashow LS, Weller DM, (1996) Current concepts in the use of introduced bacteria for biological control: Mechanisms and antifungal metabolites. Plant-Microbe Interactions 1: 187-235.

7. Duffy BK, Ownley BH, Weller DM (1997) Soil chemical and physical properties associated with suppression of take-all of wheat by Trichoderma koningii. Phytopathology 87(11): 1118-1124.

8. Ownley BH, Weller DM, Alldredge JR (1991) Relation of soil chemical and physical factors with suppression of take-all by Pseudomonas fluorescens 2-79. IOBC/WPRS Bull 14: 299-301.

9. Ownley BH, Weller DM, Thomashow LS (1992) Influence of in situ and in vitro $\mathrm{p}^{\mathrm{H}}$ on suppression of Gaeumannomyces graminis var. tritici by Pseudomonas fluorescens 2-79. Phytopatholog 82: 178-184.

10. Fiddaman PJ, Rossall S (1994) Effect of substrate on the biosynthesis of antifungal volatiles from Bacillus subtilis. J Appl Bacteriol 76(4): 395405

11. Milner JL, Raffel SJ, Lethbridge BJ, Handelsman J (1995) Bacterial conditions that influence accumulation of zwittermicin A by Bacillus cereus UW85. Appl Microbiol Biotechnol 43(4): 685-691.
12. Milner JL, Silo-Suh L, Lee JC, He H, Clardy J, et al. (1996) Biosynthesis of kanosamine by Bacillus cereus UW85. Appl Environ Microbiol 62(8): 3061-3065.

13. Slininger PJ, MA Jackson (1992) Nutritional factors regulating growth and accumulation of phenazine 1-carboxylic acid by Pseudomonas fluorescens 2-79. Appl Microbiol Biotechnol 37(3): 388-392.

14. Connell KP, Goodman RM, Handelsman J, (1996) Engineering the rhizosphere: expressing a bias. Trends Biotechnol 14(3): 83-88.

15. Lugtenberg B Kamilova F (2009) Plant Growth Promoting Rhizobacteria. Annu Rev Microbiol 63: 541-556.

16. Duffy BK, Defago G (1997) Zinc improves biocontrol of Fusarium crown and root rot of tomato by Pseudomonas fluorescens and represses the biosynthesis of pathogen metabolites inhibitory to bacterial antibiotic biosynthesis. Phytopathology 87(12): 1250-1257.

17. Haas D, Defago G (2005) Biological control of soil-borne pathogens by fluorescent pseudomonads. Nat Rev Microbiol 3(4): 307-319.

18. Voisard C, Bull C, Keel C, Laville J, Maurhofer M, et al. (1994) Biocontrol of root diseases by Pseudomonas fluorescens CHA0: Current concepts and experimental approaches. In: F. O'Gara, D Dowling et al. (Eds.), Molecular Ecology of Rhizosphere Microorganisms. VCH Publishers, Weinheim, Germany, p. 67-89.

19. Brencic A, Stephen C Winans (2005) Detection of and Response to Signals Involved in Host-Microbe Interactions by Plant-Associated Bacteria. Microbiol Mol Biol Rev. 69(1): 155-194.

20. Lapouge K, Schubert M, Allain FH, Haas D (2008) Gac/Rsm signal transduction pathway of gamma-proteobacteria: From RNA recognition to regulation of social behaviour. Mol Microbiol 67(2): 241-253.

21. Majdalani N, Vanderpool CK, Gottesman S (2005) Bacterial small RNA regulators. Crit Rev Biochem Mol Biol 40(2): 93-113.

22.Zuber S, Carruthers F, Keel C, Mattart A, Blumer C, et al. (2003) GacS sensor domains pertinent to the regulation of exoproduct formation and to the biocontrol potential of Pseudomonas fluorescens CHA0. Mol Plant-Microbe Interact 16(7): 634-644.

23. Heeb S, Haas D, (2001) Regulatory roles of the GacS/GacA two component system in plant-associated and other Gram-negative bacteria. Mol Plant-Microbe Interact 14(12): 1351-1363.

24. Maurhofer M, Keel C, Haas D, Defago G (1995) Influence of plant species on disease suppression by Pseudomonas fluorescens CHAO with enhanced antibiotic biosynthesis. Plant Pathol 44(1): 44-50.

25. Schnider U, Keel C, Blumer C, Troxler J, Defago G, et al. (1995) Amplification of the housekeeping sigma factor in Pseudomonas fluorescens $\mathrm{CHA} 0$ enhances antibiotic production and improves bio control abilities. J Bacteriol 177(18): 5387-5392.

26. Sarniguet A, Kraus J, Henkels MD, Muehlchen AM, Loper JE (1995) The sigma factor $\sigma^{s}$ affect antibiotic production and biological control activity of Pseudomonas fluorescens Pf-5. Proc Natl Acad Sci USA 92(26): 12255-12259.

27. Duffy BK, Defago G (1999) Environmental factors modulating antibiotic and siderophore biosynthesis by Pseudomonas fluorescens bio control strains. Appl Environ Microbiol 65(6): 2429-2438.

28. Notz R, Maurhofer M, Schnider-Keel U, Duffy B, Haas D, et al. (2001) Biotic factors affecting expression of the 2, 4-diacetylphloroglucinol biosynthesis gene in Pseudomonas fluorescens bio control strain CHA0 in the rhizosphere. Phytopathology 91(9): 873-881.

29. Notz R, Maurhofer M, Dubach H, Haas D, Defago G, (2002) Fusaric acid-producing strains of Fusarium oxysporum alter 2, 4-diacetylphloroglucinol biosynthetic gene expression in 
Pseudomonas fluorescens CHAO in vitro and in the rhizosphere of wheat. Appl Environ Microbiol 68(5): 2229-2235.

30. Martin JF, Marcos AT, Martin A, Asturias JA, Liras P (1994) Phosphate control of antibiotic biosynthesis at the transcriptional level In: A Torriani-Gorini, E Yagil, et al. (Eds.), Phosphate in microoganisms. ASM Press, Washington, USA, pp. 14-147.

31. Maria Pechy Tarr, Melanie Bottiglieri, Sophie Mathys, Kirsten Bang Lejbolle, Ursula Schnider-Keel, et al. (2005) RpoN $\left(\sigma^{54}\right)$ Controls Production of Antifungal Compounds and Biocontrol Activity in Pseudomonas fluorescens CHA0. Mol Plant-Microbe Interact 18(3): 260-272.

32. De Weert S, Kuipe I, Lagendijk EL, Lamers GEM, Lugtenberg BJJ (2004) Role of chemotaxis toward fusaric acid in colonization of hyphae of Fusarium oxysporum $\mathrm{f}$.

33. Martínez I, Zhu J, Lin H, Bennett GN, San KY (2008) Replacing Escherichia coli NAD-dependent glyceraldehydes-3-phosphate dehydrogenase (GAPDH) with a NADP dependent enzyme from Clostridium acetobutylicum facilitates NADPH dependent pathways. Metab Eng 10: 352-359.

34. Mac Gregor CH, Wolff JA, Arora SK, Hylemon PB, Phibbs PV (1992) Catabolite repression control in Pseudomonas aeruginosa. In E Galli, S Silver, et al. (Eds.), Pseudomonas: molecular biology and biotechnology. American Society for Microbiology, Washington, USA, pp. 198-206.
35. Weinberg ED (1977) Mineral element control of microbial secondary metabolism, In ED Weinberg (Ed.), Microorganisms and minerals. Marcel Dekker, New York, USA, pp. 289-316.

36. Glew RH, Saha AK, Das S, Remaley AT (1988) Biochemistry of the Leishmania species. Microbiol Rev 52(4): 412-432.

37. Hunter T (1995) Protein kinases and phosphatases: the yin and yang of protein phosphorylation and signalling. Cell 80(2): 225-236.

38. Dekleva ML, Strohl WR (1987) Glucose stimulated acidogenesis by Streptomyces peucetius. Can J Microbiol 33(12): 1129-1132.

39. Slininger P, MA Shea-Wilbur (1995) Liquid-bacterial $\mathrm{p}^{\mathrm{H}}$, temperature, and carbon (not nitrogen) source regulate phenazine productivity of the take-all bio control agent Pseudomonas fluorescens 2-79. Appl Microbiol Biotechnol 43(5): 794-800.

40. Whistler CA, VO Stockwell, Loper JE (2000) Lon protease influences antibiotic production and UV tolerance of Pseudomonas fluorescens Pf-5. Appl Environ Microbiol 66(7): 2718-2725.

41. Baehler E, Bottiglieri M, Pechy-Tarr M, Maurhofer M, Keel C (2005) Use of green fluorescent protein-based reporters to monitor balanced production of antifungal compounds in the biocontrol agent Pseudomonas fluorescens CHA0. J Appl Microbiol 99(1): 24-38.

42. Shanahan P, O’Sullivan DJ, Simpson P, Glennon JD, O'Gara F (1992) Isolation of 2, 4-diacetylphloroglucinol from a fluorescent pseudomonad and investigation of physiological parameters influencing its biosynthesis. Appl Environ Microbiol 58(1): 353-358.

\section{Your next submission with Juniper Publishers will reach you the below assets}

- Quality Editorial service

- Swift Peer Review

- Reprints availability

- E-prints Service

- Manuscript Podcast for convenient understanding

- Global attainment for your research

- Manuscript accessibility in different formats

( Pdf, E-pub, Full Text, Audio)

- Unceasing customer service

Track the below URL for one-step submission https://juniperpublishers.com/online-submission.php 